YEARBOOK

of ANTITRUST

and REGULATORY

STUDIES

www.yars.wz.uw.edu.pl
Peer-reviewed scientific periodical, focusing on legal and economic issues of antitrust and regulation. Creative Commons Attribution-No Derivative Works 3.0 Poland License.

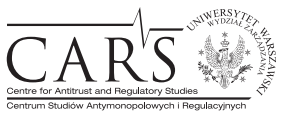

Centre for Antitrust and Regulatory Studies, University of Warsaw, Faculty of Management www.cars.wZ.uw.edu.pl

\title{
The Damages Directive and Consensual Approach to Antitrust Enforcement
}

\author{
by
}

Raimundas Moisejevas*

\section{CONTENTS}

I. Introduction

II. The benefits of Alternative Dispute Resolution methods for actions for damages

III. The Damages Directive and consensual dispute resolution

1. Reasons for the introduction into the Damages Directive of a section on consensual dispute resolution

2. Suspension of the limitation period and pending proceedings

3. Benefits for the settling infringer

4. Effect of decisions of National Competition Authorities and national courts

5. Disclosure of evidence and quantification of harm

IV. Some thoughts on the status of the use of Alternative Dispute Resolution in practice

V. Conclusions

\section{Abstract}

The article focuses on the novelties introduced by the Damages Directive in the field of consensual settlements of disputes concerning private enforcement. The Damages Directive obliges Member States to ensure that the limitation period for bringing an action for damages is suspended for the duration of any consensual dispute resolution process. The Directive also establishes the main principles that govern the effect of consensual settlements on subsequent actions for damages.

* Dr Raimundas Moisejevas is a practising Competition Advocate, ICSID Conciliator and Associated Professor in the Business Law Department, Faculty of Law, Mykolas Romeris University, Lithuania; email: raimundas11@yahoo.com. 
Since the EU framework for consensual dispute resolution of private enforcement disputes is quite new, many issues must still be solved in Member States' practice. While analysing consensual dispute resolution in private enforcement cases, particular interest should be paid to mediation and arbitration as a form of Alternative Dispute Resolution (ADR). Mediation is often used in competition law litigation. In a mediation process, parties are subject to fewer legal costs than in litigation and arbitration. It may thus be concluded that consensual dispute resolution is usually a faster way to receive compensation. However, voluntary arrangements and ADR in competition law still raise many problems concerning both procedural and substantial legal acts.

\section{Résumé}

Cet article porte sur les nouveautés introduites par la Directive relative aux actions en dommages dans le domaine de règlement consensuelle des litiges concernant l'exécution privée du droit de la concurrence. La Directive oblige les États membres à assurer que le délai de prescription fixé pour intenter une action en dommages est suspendu pour la durée de tout procédure de règlement consensuel du litige. La Directive établit également les principes concernant l'effet des règlements consensuels sur les actions en dommages subséquentes. Etant donné que le cadre européen pour le règlement consensuelle des litiges concernant l'exécution privée $\mathrm{du}$ droit de la concurrence est relativement neuf, de nombreuses questions doivent être encore résolues dans la pratique des États membres. En analysant le règlement consensuelle des litiges concernant l'exécution privée du droit de la concurrence, un intérêt particulier devrait être accordée à la médiation et à l'arbitrage, comme des modes alternatifs de résolution des conflits (MARC). La médiation est souvent utilisée dans les litiges en droit de la concurrence. Dans un processus de médiation, les parties sont soumises aux frais juridiques moins élevés que dans le cas d'un procédure judiciaire ou d'arbitrage. Nous pouvons donc conclure que le règlement consensuelle des litiges est généralement le moyen plus rapide pour recevoir une compensation. Toutefois, des accords volontaires et le MARC posent encore de nombreux problèmes substantiels et procédurales en droit de la concurrence.

Key words: antitrust damage; consumers; arbitration; alternative dispute resolution; mediation; consensual dispute resolution; Lithuania; private enforcement of competition law; antitrust damage claims; Directive on antitrust damages actions; consensual settlements.

JEL: K23; K42. 


\section{Introduction}

For quite a long time, it was considered impossible to arbitrate competition law. The situation changed with the adoption of the Mitsubishi Motors Corp. v. Soler Chrysler Plymouth, Inc. decision by the US Supreme Court in 1985'. The US Supreme Court recognized therein that a US federal antitrust claim was arbitrable in international matters. In Europe, the Court of Justice accepted the arbitrability of EU competition law in 1999 in the Eco Swiss case ${ }^{2}$. The European Commission (hereafter, EC or Commission) recognized that arbitration tribunals could decide damages actions in its Directive 2014/104/ EU on antitrust damages actions (hereafter, Damages Directive) and in the EC's Practical guide quantifying harm in actions for damages ${ }^{3}$.

It should be noted that the recognition of the arbitrability of competition law by the Court of Justice has not inspired a unanimous position in all EU Member States. For example, the Lithuanian Law on Commercial Arbitration prohibited the arbitration of all competition law issues even until 30 June $2012^{4}$. The Lithuanian Law on Commercial Arbitration provides that arbitrable commercial disputes include disputes related also to breaches of competition law only since the 2012 amendment $^{5}$.

The EC claims that hard-core cartels with effects across the EU cause damages to consumers and other victims in the EU ranging yearly from approximately $€ 13$ billion (most conservative assumptions) to over $€ 37$ billion (least conservative estimation) ${ }^{6}$. Any rules that could help consumers recover such damages are thus welcomed. Alternative Dispute Resolution (hereafter, ADR) could help collective-redress since claims could be resolved cheaper and faster than through litigation. Injured parties are expected to have more

${ }^{1}$ Mitsubishi Motors Corp. v. Soler Chrysler Plymouth, Inc., 473 U.S. 614 (1985) decision by the United States Supreme Court.

2 Case C-126/97 Eco Swiss China Time Ltd v. Benetton International NV [1999] ECR, I-3055.

3 Commission Staff Working Document 'Practical guide quantifying harm in actions for damages based on breaches of Article 101 or 102 of the Treaty on the Functioning of the European Union' (SWD (2013)) C (2013) 3440).

${ }^{4}$ Lietuvos Respublikos komercinio abitražo įstatymas (1996 m. balandžio 2 d. įstatymo redakcija Nr. I-1274) // Valstybės žinios. 1996. Nr. 39-961 [The Republic of Lithuania Law on Commercial Arbitration].

5 Lietuvos Respublikos komercinio abitražo įstatymas (2012 m. birželio 30 d. įstatymo redakcija Nr. XI-2089) // Valstybės žinios. 2012. Nr. 76-3932 [The Republic of Lithuania Law on Commercial Arbitration].

${ }^{6}$ Commission Staff Working Document. Impact Assessment Report. 'Damages actions for breach of the EU antitrust rules' (SWD (2013)) 2013 final p. 22. 
alternatives how to seek redress 7 . This should be especially beneficial for consumers which do not usually have so-called 'deep pockets'.

The Damages Directive was signed into law on 26 November 2014 and published in the Official Journal of the European Union on 5 December $2014^{8}$. This Directive has introduced a number of new measures intended to facilitate private enforcement claims in EU Member States. One of the novelties brought about by the Damages Directive lies in a number of rules for the voluntary settlement of private enforcement disputes. Importantly here, the Directive obliges Member States to ensure that the limitation period for bringing an action for damages is suspended for the duration of any consensual dispute resolution process. Moreover, it establishes the main principles that shall govern the effect of consensual settlements on subsequent actions for damages. The Damages Directive in fact encourages parties to resolve their disputes by negotiating and avoiding the need to go to court. Since the above EU framework for consensual dispute resolution of private enforcement disputes is quite new, many issues must still be solved in the practice of EU Member States.

The main objective of this article is to analyze the novelties that the Damages Directive has brought about in the field of consensual settlement of private enforcement cases. The author does not attempt to thoroughly analyse all aspects of mediation and arbitration, or to present a comprehensive comparative study of ADR in private enforcement. The main goal of this article is to provide the reader with an analysis of the main features of the Damages Directive as far as it deals with consensual dispute settlement. The above-defined objective is pursued by scrutinising: the provisions of the Directive itself; certain relevant documents of EU Member States; EU case law; as well as the decisions of the Lithuanian Competition Council and the jurisprudence of Lithuanian administrative courts. It must be said, however, that as it has not been long since the Damages Directive was actually signed into law (end of 2014), there is very little relevant literature on the subject matter of this article. Moreover, there is practically no relevant case law or literature in Lithuania, which could help provide a comprehensive analysis on consensual dispute settlement in competition law. This article is likely to be one of the first Lithuanian papers devoted to such topic. The subject matter of the research of this article was analysed with the help of a logical, systematic analysis and comparative and linguistic research methods.

7 C.H. Bovis, C.M. Clarke, 'Private Enforcement of EU Competition Law' (2015) 36 Liverpool Law Review 49-71.

8 Directive 2014/104/EU of the European Parliament and of the Council of 26 November 2014 on certain rules governing actions for damages under national law for infringements of the competition law provisions of the Member States and of the European Union, OJ L 349, 05.12 .2014 , p. 1 . 


\section{The benefits of Alternative Dispute Resolution methods for actions for damages}

Alternative Dispute Resolution could be beneficial both for the infringers and for the injured parties. When the infringer recognizes its infringement and wishes to pay compensation, then ADR provides the perfect opportunity to do so. Moreover, ADR allows consumers or other injured parties to recover compensation without high legal costs. The European Parliament has stated that ADR mechanisms could help avoid a considerable amount of litigation. The setting-up of ADR schemes at European level should thus be encouraged since fast and cheap settlement of disputes is a more attractive option than court proceedings 9 . The EC claims that in relation to a mass harm situation the parties should be encouraged to reach a consensual dispute settlement concerning relevant compensation both at the pre-trial stage and during civil trials, taking into account Directive 2008/52/EC of the European Parliament and of the Council of 21 May 2008 on certain aspects of mediation in civil and commercial matters ${ }^{10}$. The policy of EU institutions is thus that litigation should be treated as the last resort only ${ }^{11}$.

Like the EC, some Member States express support for the use of ADR in competition disputes. For example, the British Government announced in 2012 a Consultation on private actions in competition law and $\mathrm{ADR}^{12}$. Support for the British Government's proposal on the use of ADR to solve competition disputes was expressed by lawyers, a number of academics, as well as consumer and business representatives ${ }^{13}$. The British Government claims in the 2012 consultation that 'cases being resolved through alternative means, avoiding court involvement, can be a more satisfactory outcome for all parties as well as reducing burdens on the state; ... an extension of private actions through the reforms above would be more effective and less expensive if matched by increased Alternative Dispute

9 European Parliament Resolution of 2 February 2012 'Towards a Coherent European Approach to Collective Redress' (2011/2089(INI)).

10 Commission Recommendation of 11 June 2013 on common principles for injunctive and compensatory collective redress mechanisms in the Member States concerning violations of rights granted under Union Law (2013/396/EU).

11 C. Hodges, 'Fast, Effective and Low Cost Redress: How Do Public and Private Enforcement and ADR Compare?' [in:] B. Rodger (ed.), Competition Law. Comparative Private Enforcement and Collective Redress Across the EU, Kluwer Law International 2014, 328 pp.

12 Department of Business Innovation and Skills, Private Actions in Competition Law: A Consultation on Options for Reform, available at http://bis.gov.uk/assets/biscore/consumerissues/docs/p/12-742-private-actions-in-competition-law-consultation.pdf.

13 C. Hodges, Delivering Competition Damages in UK, available at http://www.csls.ox.ac.uk/ documents/1208Howwouldcompensationbedeliveredinfuture.pdf. 
Resolution (ADR)'14. The British Government even proposed to make ADR the default first option in competition cases, although not mandatory ${ }^{15}$.

There are many proposals how to solve disputes between consumers and businesses in competition and other areas. The EC is considering the adoption of ADR systems for consumers ${ }^{16}$ - it even believes that ADR means should be available in relation to every type of dispute between a consumer and a business ${ }^{17}$. The EC Work Programme for 2011 identified consumer ADR as one of the Commission's strategic proposals for that year ${ }^{18}$. It may be expected that ADR mechanisms will continue to grow with respect to competition disputes, as well as other areas. Undertakings that value their reputation might be particularly inclined to use ADR mechanisms to solve their disputes arising with consumers or other businesses.

In the above mentioned 2012 Consultation on private actions in competition law and ADR, the British Government summarised somewhat the benefits and potential risks of $\mathrm{ADR}^{19}$. It was stated that the primary benefits of $\mathrm{ADR}$ are: restoration of a positive working relationship between the parties; making it possible to quickly resolve the underlying problem; a defence for both parties from uncertainties and costs of litigation; and, reducing court costs for the State. Clearly, the importance of the above issues might differ in separate cases. For example, consultations with businesses disclosed that the removal of barriers for business relationships is often more important than receiving monetary compensation.

A number of issues were also identified as potential risks of ADR: the creation of additional arbitrary burdens on claimants and defendants; opportunity for lawyers to increase the costs of a case through a long pretrial process; creating a system that largely promotes ADR and diminishes the possibility of cases reaching the courts, reducing the pressure to actually achieve a settlement; allowing the party with better access to information (the defendant in most cases) to exercise pressure on its counterparty. The last risk concerning access to information is especially important in competition law cases for a number of reasons such as: it might not be clear what evidence supports the case; the quantity of the redress and the number of the potential recipients of the redress might also not be easy to determine.

14 Department of Business Innovation and Skills, supra note 12.

15 Ibidem.

16 Communication from the European Commission 'Alternative dispute resolution for consumer disputes in the Single Market', COM (2011) 791 final.

17 Commission (EC), 'Proposal for a Directive on alternative dispute resolution for consumer disputes', COM (2011) 793/2, final 29 November 2011 and Commission (EC), 'Proposal for a Regulation on online dispute resolution for consumer disputes', COM (2011) 794/2, final, 29 November 2011.

18 Commission Legislative Work Programme for 2011, COM (2010) 623.

19 Department of Business Innovation and Skills, supra note 12. 


\section{The Damages Directive and consensual dispute resolution}

\section{Reasons for the introduction into the Damages Directive of a section on consensual dispute resolution}

The Damages Directive deals mainly with rules governing actions for damages. However, according to its Preamble, actions for damages are just one element of an effective system of private enforcement of competition law. Hence, they should be complemented by alternative tools of redress such as consensual dispute resolution that provides parties with an incentive to give compensation. The Preamble of the Damages Directive envisages also that infringers and injured parties should be encouraged to agree on compensating for the harm caused by a competition law violation through consensual dispute resolution mechanisms such as out-of-court settlements, arbitration, mediation or conciliation. The Directive does not mention expresis verbis expert determination as an ADR mechanism. However, it is justified to say that expert determination of competition issues could be used in certain private enforcement $\operatorname{cases}^{20}$. Expert determination is especially important bearing in mind all the difficulties related to private enforcement and frequent requests for expert opinion in such cases.

The provisions of the Damages Directive on consensual dispute resolution aim to facilitate the use of such mechanisms and increase their effectiveness ${ }^{21}$. It will be analyzed below what influence the provisions of the Damages Directive may have on the arbitration of competition law.

\section{Suspension of the limitation period and pending proceedings}

Article 18(1) of the Damages Directive stipulates that the limitation period for bringing an action for damages shall be suspended for the duration of any consensual dispute resolution process. Of course, if the parties have an agreement with an arbitration clause, they will in any case be obliged to use arbitration instead of litigation for resolving a dispute. The arbitration procedure would thus produce a result in the same way as a litigation procedure. Agreeing with Miriam Driessen-Reilly, Article 18(1) of the Damages Directive deals, in essence, with situations when the parties attempt to resolve the case primarily through mediation or conciliation without referring to arbitration/

20 T. Zuberbuler, C. Oetiker (eds.), Practical Aspects of Arbitrating EC Competition Law, Schulthess 2007, p. 103-112.

21 Paragraphs 5, 48-52 of the Damages Directive. 
litigation ${ }^{22}$. In case the parties do not resolve their dispute through mediation, arbitration/litigation will then follow afterwards.

Mediation is well established in competition law disputes. Through mediation, the parties may get all the benefits of litigation without substantial legal costs. According to one of the documents prepared by the OECD, two types of competition law disputes are mediated: follow-on claims for damages and disputes concerning ongoing relationships in an industry ${ }^{23}$. Mediation might be especially important if businesses aim to re-establish a normal relationship and continue generating profits.

Moreover, Article 18(2) of the Damages Directive stipulates that without prejudice to the provisions of national laws in matters of arbitration, Member States shall ensure that national courts dealing with a damages action may suspend their proceedings for up to two years if the parties are involved in consensual dispute resolution concerning the claim covered by that action for damages. Most probably, these cases will deal with situations when the parties had already started a litigation procedure before a court but have afterwards decided to choose mediation/conciliation. This provision does not refer to arbitration because if the parties have an arbitration clause, then the case is decided in an arbitral tribunal instead of a court. In any case, such clause is welcomed as it encourages out-of-court settlements ${ }^{24}$.

\section{Benefits for the settling infringer}

The Damages Directive aims to encourage consensual settlement and provides that an infringer who pays damages through consensual dispute resolution should not be placed in a worse position than its co-infringers. A settling infringer should, therefore, not be fully jointly and severally liable for the harm caused by the entire infringement. After the settlement, the injured party is entitled to recover compensation only from the other nonsettling infringers. However, it is possible that non-settling infringers would prove unable to pay their own dues and then theoretically, the injured party could once again make a claim against an infringer that has already settled its own damages. This principle follows from Article 11 of the Damages Directive

${ }^{22}$ M. Driessen-Reilly, 'Private damages in EU competition law and arbitration - a changing landscape' (2015) Arbitration International 6.5.2015, http://dx.doi.org/10.1093/arbint/aiv007.

23 OECD, Hearings, Arbitration and Competition, DAF/COMP(2010)40, p. 10, available at http://www.oecd.org/competition/abuse/49294392.pdf.

${ }^{24}$ S. Peyer, 'The Antitrust Damages Directive - much ado about nothing' [in:] M. Marquis, R. Cisotta, Litigation and Arbitration in EU Competition Law, Edward Elgar Publishing 2015, pp. 33-46. 
that establishes the maxim of joint and several liability. In view of the above, the settling infringer should aim to ensure that the consensual settlement includes a clause on the exclusion of its further liability for any damages that prove impossible to recovered by non-settling infringers. Indeed, Article 19 of the Damages Directive expresis verbis provides for the possibility to amend a consensual settlement by expressly excluding additional liability.

Article 18(4) of the Damages Directive provides that a competition authority may consider compensation paid on the basis of a consensual settlement prior to its infringement decision to be a mitigating factor when imposing a fine. It is not clear how this provision will be transposed into national competition laws and how National Competition Authorities (hereafter, NCAs) will use this provision in practice. Moreover, antitrust damages claims are usually submitted as follow-on actions in EU Member States. It can be presumed that most consensual settlements will follow a prior infringement decision issued by a NCA. The application of the principle established in Article 18(4) of the Damages Directive will thus likely be quite uncommon.

\section{Effect of decisions of National Competition Authorities and national courts}

Article 9(1) of the Damages Directive provides that an infringement of competition law found by a final decision of a NCA or by a reviewing court is deemed to be irrefutably established for the purposes of an action for damages brought before their national courts under Article 101 or 102 of TFEU or under the provisions of domestic competition law. At the same time, Article 9(2) of the Damages Directive provides that when the decision of a NCA is taken in another Member State, then such final decision could be presented before domestic courts only as prima facie evidence. It is unclear how an arbitral tribunal should act in the same circumstances. It is also questionable whether, under the basic principles of arbitration law, the decision of a domestic NCA should have more legitimacy than the decision of a foreign $\mathrm{NCA}^{25}$. This question remains to be answered in the national practice of EU Member States.

\section{Disclosure of evidence and quantification of harm}

Articles 5-8 of the Damages Directive consider the disclosure and use of evidence in damages action cases but the above-mentioned provisions do not refer to arbitral tribunals. Moreover, according to the practice of the Court

25 M. Driessen-Reilly, supra note 22. 
of Justice, arbitral tribunals are not considered to be 'courts' according to the TFEU. On the other hand, the Damages Directive obliges Member States to transpose certain mandatory procedural rules that shall govern the disclosure of evidence in damages action cases. Since arbitral tribunals are obliged to respect mandatory provisions of national law, arbitral tribunals will probably have to follow the rules on the disclosure of evidence established in the Damages Directive. Arbitral tribunals might also have to amend their rules on the disclosure of evidence. Bearing in mind all of the above-mentioned circumstances, it is clear that the Damages Directive is likely to have quite a significant effect on arbitration proceedings.

The Damages Directive does not cover exhaustively the 'quantification of harm' issue but the Practical guide quantifying harm in actions for damages (hereafter, Practical guide) is helpful in this matter ${ }^{26}$. However the latter document might, in some cases, not offer sufficient guidance and consulting a NCA might also be necessary. Article 17 of the Damages Directive provides that national court may request a NCA to assist them with respect to the determination of the quantum of damages. Like in many matter mentioned above, a problem might arise here since the Damages Directive does not grant the same right to an arbitral tribunal (that is, to request assistance from a NCA). Therefore, the way in which NCAs interact with arbitral tribunals might be different than how they treat the judiciary. However, as far as is known from the practice in Lithuania, arbitral tribunals do sometimes receive assistance from the domestic NCA.

\section{Some thoughts on the status of the use of Alternative Dispute Resolution in practice}

According to the EC, one of the main aims behind the adoption of the Damages Directive is the idea that private enforcement of competition law should be strongly encouraged, considering that this area is currently undeveloped. A couple of studies showed an increase in private enforcement cases in the UK and in Germany ${ }^{27}$. However, after analyzing existing private enforcement cases, a claim can be made that the existing jurisprudential evidence is merely the tip of the iceberg - most competition law disputes lead

26 Commission Staff Working Document 'Practical guide quantifying harm in actions for damages based on breaches of Article 101 or 102 of the Treaty on the Functioning of the European Union' (SWD (2013)) C (2013) 3440).

27 B. Rodger, 'Competition Law Litigation in the UK Courts: A Study of All cases to 2004' (2006) ECLR 241-8, Parts I-III; B. Rodger, 'Competition Law Litigation in the UK Courts: AStudy of all Cases 2005-2008’ (2009) GCLR 93-114 and 136-47, Parts I and II. 
to unreported out-of-court settlements ${ }^{28}$. In the first study, Professor Rodger undertook the empirical research of 43 settlements reached in the UK between 2000 and 2005. The fact that he found that only one of these settlements was actually known to the public speaks for itself. Professor Rodger recently claimed that 'uncertainty of litigation was the key settlement motivation, and the principal difficulties in pursuing a competition law case were the evidential issues, legal uncertainty and economic difficulties ${ }^{29}$. There is hope that settling parties shall have more clarity as to their position after the implementation of the Damages Directive and the expected increase in certainty of national legal rules. At the same time, however, the clear establishment of the rules on damages actions may also increase the amount of judicial litigation.

It should be noted that publicly available judgments of Lithuanian courts do not reflect all of this nation's antitrust damages claims either. The author has personally dealt with a couple of publicly unreported private enforcement cases submitted to arbitral tribunals in Lithuania. The public remain unaware of many more competition law based claims that have been submitted for $\operatorname{arbitration}^{30}$.

Consumers' interests are currently not represented in private enforcement litigation or/and settlements. Consumer damage had been clearly established because of cartels in a number of cases in Europe yet there were no follow-on action by consumer associations, let alone by private consumers. In Lithuania, only undertakings have even submitted actions for antitrust damages consumers have so far never acted as claimants ${ }^{31}$. One claim submitted in the UK can be mentioned which was brought forward by a consumer association in the case United Kingdom against JJB Sports PLC ${ }^{32}$. The UK Consumer Association represented 144 consumers - the case ultimately settled with an agreement to pay up to 20 pounds to each of the represented consumers.

After analysing private enforcement cases from Poland, Latvia, Estonia, Slovakia and Lithuania, as well as other countries from Central and Eastern Europe, it came as no surprise that most of them centre on an abuse of dominance case and took the form of follow-on actions ${ }^{33}$. The author has

28 B. Rodger, 'Private Enforcement of Competition Law, The Hidden Story: Competition Litigation Settlements in the UK 2000-2005' (2008) ECLR 96-116.

${ }_{29}$ B. Rodger, 'Why not court? A study on follow-on actions in the UK' (2013) 1(1) Journal of Antitrust Enforcement 104-131.

${ }^{30}$ R. Moisejevas, 'Development of Private Enforcement of Competition Law in Lithuania' (2015) 8(11) YARS.

31 Ibidem.

32 The Consumers' Association v. JJB Sports plc. (CAT Case 1078/7/9/07).

33 M. Brkan, T. Bratina, 'Private Enforcement of Competition Law in Slovenia: A New Field to Be Developed by Slovenian Courts' (2013) 6(8) YARS 75-106; A. Jurkowska-Gomułka, 'Private Enforcement of Competition Law in Polish Courts: The Story of an (Almost) Lost 
made this analysis in an earlier article ${ }^{34}$. The above conclusion may have a number of explanations. First, it might be simpler to determine and to prove an abuse of dominance case than an anti-competitive agreement. Second, a company that suffered from an abuse might be more inclined to present a claim to the court, or approach the Lithuanian Competition Council, than a company which was a counterpart in an anti-competitive agreement since the Lithuanian Competition Council could end up imposing a fine on both undertakings that have concluded the anti-competitive agreement. Third, for those not party to an anti-competitive agreement, it is difficult to collect evidence on its functioning. An undertaking may suffer damages because of an anti-competitive agreement, but it might have no information about the existence of such agreement.

In another study, Lande and Davis have researched 40 private settlement cases in the US decided between 1988 and 2005 ${ }^{35}$. Almost half of them were standalone actions uncovered by private attorneys. The importance of follow-on actions has thus recently decreased in the US ${ }^{36}$. It is not clear whether the same tendency could appear in the EU considering that the US legal system is more developed in the private enforcement area. In the opinion of Professor Rodger, the main criterion for deciding whether to rely on follow-on or standalone action lies in the 'type' of the relevant anti-competitive practice $^{37}$. Unsurprisingly, cartel cases mainly generate follow-on actions since any potential claimants (especially consumers) usually do not have access to information on the fact that a given anti-competitive agreement has infringed their interests. On the other hand, claimants harmed through an abuse of dominance often understand that an abusive action has been committed and frequently induce an investigation in such matters by competition authority. Due to the above-mentioned circumstances, and difficulties in uncovering evidence, most private enforcement cases in the EU take the form of follow-on actions and are submitted by undertakings (rather than consumers/consumer associations) - they follow after a decision of a NCA that recognizes that a certain company had engaged in the abuse of dominance.

Hope for Development' (2013) 6(8) YARS 107-128; A. Piszcz, 'Still-unpopular Sanctions: Developments in Private Antitrust Enforcement in Poland After the 2008 White Paper' (2012) 5(7) YARS 55-77; K. Sein, 'Private Enforcement of Competition Law - the Case of Estonia' (2013) 6(8) YARS 129-140.

34 R. Moisejevas, supra note 30.

35 R.H. Lande, J.P. Davis, 'Benefits from Private Antitrust Enforcement: An Analysis of Forty Cases' (2008) 42 USFL Review 879-918.

${ }^{36}$ M.T. Vanikiotis, 'Private Antitrust Enforcement and Tentative Steps Toward Collective Redress in Europe and the United Kingdom' (2014) 37(5) Fordham International Law Journal 1639-1682; R.H. Lande, J.P. Davis, supra note 35.

37 B. Rodger, supra note 29. 


\section{Conclusions}

Arbitral tribunals are handling a huge number of competition cases albeit cases handled by arbitrators or mediators are often kept confidential. It is difficult to foresee what real effect the Damages Directive shall have on substantial and procedural rules of arbitration and other forms of ADR. There is reason to believe that the Directive might encourage recourse to ADR in competition law disputes. The Directive clarified rules on how evidence should be evaluated by parties to a dispute and arbitral tribunals, provisions on the amount of damages and on joint and several liability of co-infringers, as well as the legal value of decisions issued by NCAs. The new rules give clear benefits to both infringers and injured parties to achieve a consensual settlement. A fully comprehensive analysis of the effects of the Damages Directive on ADR in private enforcement cases can only be performed after a number of years have passed since its transposition into the national competition laws of EU Member States.

So far, the vast majority of all private enforcement claims (all private enforcement claims in Lithuania) was brought forward by undertakings - there have been almost no antitrust damages claims ever submitted by consumers or their associations. It remains to be seen whether consumers will make use of the Damages Directive. Following a ADR mechanism could help collective redress since claims could be solved cheaper and faster than through litigation. Injured parties shall have more alternatives how to seek redress. This is especially beneficial for consumers because they usually do not have 'deep pockets'. It is also possible that the establishment of group actions might create a legal platform for consumers to submit antitrust damages claims and/or to be more effective in achieving consensual settlements.

\section{Literature}

Bovis C.H., Clarke C.M, 'Private Enforcement of EU Competition Law' (2015) 36 Liverpool Law Review.

Brkan M., Bratina T., 'Private Enforcement of Competition Law in Slovenia: A New Field to Be Developed by Slovenian Courts' (2013) 6(8) YARS.

Private Actions in Competition Law: A Consultation on Options for Reform (Department of Business Innovation and Skills, 2012), Available at http://bis.gov.uk/assets/biscore/ consumer-issues/docs/p/12-742-private-actions-in-competition-law-consultation.pdf.

Driessen-Reilly M., 'Private damages in EU competition law and arbitration - a changing landscape' (2015) Arbitration International.

Hodges C., 'Fast, Effective and Low Cost Redress: How Do Public and Private Enforcement and ADR Compare?' [in:] B. Rodger (ed.), Competition Law. Comparative 
Private Enforcement and Collective Redress Across the EU, Kluwer Law International 2014.

Hodges C., Delivering Competition Damages in UK, http://www.csls.ox.ac.uk/documents/12 08Howwouldcompensationbedeliveredinfuture.pdf

Jurkowska-Gomułka A., 'Private Enforcement of Competition Law in Polish Courts: The Story of an (Almost) Lost Hope for Development' (2013) 6(8) YARS.

Lande R.H., Davis J.P., 'Benefits from Private Antitrust Enforcement: An Analysis of Forty Cases' (2008) 42 USFL Review.

Maria Teresa Vanikiotis, 'Private Antitrust Enforcement and Tentative Steps Toward Collective Redress in Europe and the United Kingdom', Fordham International Law Journal, Volume 37, Issue 5, 2014, Article 6, 1639-1682.

Moisejevas R., 'Development of Private Enforcement of Competition Law in Lithuania' (2015) 8(11) YARS.

OECD, Hearings, Arbitration and Competition, DAF/COMP(2010), http://www.oecd.org/ competition/abuse/49294392.pdf.

Peyer S., 'The Antitrust Damages Directive - much ado about nothing. Litigation and Arbitration in EU Competition Law' [in:] M. Marquis, R. Cisotta (eds.), Litigation and Arbitration in EU Competition Law, Edward Elgar Publishing 2015.

Piszcz A., 'Still-unpopular Sanctions: Developments in Private Antitrust Enforcement in Poland After the 2008 White Paper', (2012) 5(7) YARS.

Rodger B., 'Competition Law Litigation in the UK Courts: A Study of All Cases 20052008' (2009) GCLR.

Rodger B., 'Competition Law Litigation in the UK Courts: A Study of All Cases to 2004' (2006) ECLR.

Rodger B., 'Private Enforcement of Competition Law, The Hidden Story: Competition Litigation Settlements in the UK 2000-2005' (2008) ECLR.

Rodger B., 'Why not court? A study on follow-on actions in the UK' (2013) 1(1) Journal of Antitrust Enforcement.

Vanikiotis M.T., 'Private Antitrust Enforcement and Tentative Steps Toward Collective Redress in Europe and the United Kingdom' (2014) 37(5) Fordham International Law Journal.

Weidt C.F., 'The Directive on Actions for Antitrust Damages After Passing the European Parliament' (2014) 35(9) ECLR.

Zuberbuler T., Oetiker C. (eds.), Practical Aspects of Arbitrating EC Competition Law, Schulthess 2007. 